\title{
Minor Imbalance of the Lowermost Italian Glacier from 2006 to 2019
}

\author{
Jessica De Marco 1,2**D, Luca Carturan ${ }^{3,4} \mathbb{D}^{\mathbb{D}}$, Livia Piermattei ${ }^{5}$, Sara Cucchiaro 1,3 ${ }^{\mathbb{D}}$, \\ Daniele Moro $^{6}$, Giancarlo Dalla Fontana ${ }^{3}$ (D) and Federico Cazorzi ${ }^{1}$ (D) \\ 1 Department of Agricultural, Food, Environmental and Animal Sciences (DI4A), University of Udine, Via \\ delle Scienze, 206, 33100 Udine, Italy; sara.cucchiaro@uniud.it (S.C.); federico.cazorzi@uniud.it (F.C.) \\ 2 Department of Life Sciences, University of Trieste (DSV), Via E. Weiss, 2, 34128 Trieste, Italy \\ 3 Department of Land, Environment, Agriculture and Forestry (TESAF), University of Padova, Viale \\ dell’Università, 16, 35020 Legnaro (Padova), Italy; luca.carturan@unipd.it (L.C.); \\ giancarlo.dallafontana@unipd.it (G.D.F.) \\ 4 Department of Geosciences, University of Padova, Via Gradenigo, 206, 35131 Padova, Italy \\ 5 Chair of Physical Geography, Catholic University Eichstaett-Ingolstadt, 85072 Eichstaett, Germany; \\ Livia.Piermattei@ku.de \\ 6 Autonomous Region Friuli-Venezia Giulia, Direzione Centrale Risorse Agroalimentari, Forestali e Ittiche, \\ Servizio Foreste e Corpo Forestale, Struttura Stabile Centrale per L'attività di Prevenzione del Rischio da \\ Valanga, 33100 Udine, Italy; daniele.moro@regione.fvg.it \\ * Correspondence: jessica.demarco@phd.units.it
}

Received: 13 August 2020; Accepted: 4 September 2020; Published: 8 September 2020

\begin{abstract}
The response of very small glaciers to climate changes is highly scattered and little known in comparison with larger ice bodies. In particular, small avalanche-fed and debris-covered glaciers lack mass balance series of sufficient length. In this paper we present 13 years of high-resolution observations over the Occidentale del Montasio Glacier, collected using Airborne Laser Scanning, Terrestrial Laser Scanning, and Structure from Motion Multi-View Stereo techniques for monitoring its geodetic mass balance and surface dynamics. The results have been analyzed jointly with meteorological variables, and compared to a sample of "reference" glaciers for the European Alps. From 2006 to 2019 the mass balance showed high interannual variability and an average rate much closer to zero than the average of the Alpine reference glaciers (-0.09 vs. $-1.42 \mathrm{~m}$ water equivalent per year, respectively). This behavior can be explained by the high correlation between annual balance and solid precipitation, which displayed recent peaks. The air temperature is not significantly correlated with the mass balance, which is main controlled by avalanche activity, shadowing and debris cover. However, its rapid increase is progressively reducing the fraction of solid precipitation, and increasing the length of the ablation season.
\end{abstract}

Keywords: glacier mass balance; glacier dynamics; very small glaciers; debris-covered glaciers; climate change; geodetic method; Structure from Motion (SfM); Terrestrial Laser Scanning (TLS)

\section{Introduction}

In mid- and low-latitude alpine ranges, very-small glaciers $\left(<0.5 \mathrm{~km}^{2}\right)$ account for $80-90 \%$ of the total glacier number [1-3]. Their response to the current atmospheric warming is highly scattered in comparison with larger glaciers [4-9], because the influence of local topo-climatic factors tends to be greater during times of warmer climate [10,11] and with decreasing glacier size [12-14]. For the same reason, and owing to the lack of long enough observation series, their current behavior and response mechanisms are still little known and deserve investigation. 
Small perennial ice bodies located hundreds of meters below the regional Equilibrium Line Altitude (ELA) are a common feature in mountain regions characterized by steep rock walls, such as the Dolomites, in the Eastern Italian Alps. These ice bodies were generated by large amounts of snow deposited at the base of rock walls by avalanches, leading to conspicuous net accumulation in the past centuries and decades, and generating perennial ice bodies that still persist today. In addition to snow, the rock walls release debris that are entrained in these ice bodies and tend to accumulate over their surface when/where ablation prevails over accumulation $[15,16]$. The direct consequence of this is the build-up of a debris cover that is generally thickest towards the front, and which tends to expand and thicken in periods of negative mass balance.

The mass balance of these ice bodies is highly variable in space, due to the existence of strong lateral gradients of accumulation and ablation, caused by an uneven deposition of avalanche snow, thickness of debris cover, and terrain shadowing. There is also a considerable inter-annual variability in mass balance, which is generally affected by winter precipitation, but is also controlled by the widening or shrinking of the firn area and of the debris-covered area. For example, Carturan et al. (2013) [17] highlighted how the mass balance sensitivity to temperature fluctuations of the Occidentale del Montasio Glacier (Julian Alps, Eastern Italian Alps) is closely related to the extent of firn and debris-covered areas, subject to rapid year-to-year modifications.

General assumptions concerning ELA or Accumulation Area Ratio (AAR) relationships with mass balance are not valid in these environments. In particular, the balanced-budget AAR can be considerably lower than $0.5-0.6$, which is the range normally assumed to be valid for non-calving and non-tropical glaciers [18-20]. In addition, the evolution of these ice bodies is also frequently influenced by their interaction with paraglacial and periglacial processes. In particular, when the local topo-climatic conditions are favorable, there is a tendency for glacier remnants to evolve under permafrost conditions and generate rock glaciers [21] or glacial-permafrost composite landforms [22,23].

The overlap of different processes and feedbacks (e.g., the albedo and debris cover), combined with the peculiar response to atmospheric changes and the impossibility of using "traditional" field techniques (e.g., the glaciological method) make it difficult to study and outline the evolution of these small glaciers, even in the near future. Overall, the existing literature suggests that they have a lower sensitivity to air temperature fluctuations, and a higher sensitivity to precipitation variability, compared to glaciers and glacierets unaffected by a large accumulation of avalanched snow and debris [17,24-26]. However, there is the need for improved process-oriented studies at key selected sites, which require observation series of sufficient length and detail.

New opportunities have emerged in the last two decades enabling high-frequency and high-resolution topographic surveys in areas that are otherwise inaccessible, or too dangerous to be surveyed using traditional field techniques. These opportunities are represented by the fast-evolving field of High-Resolution Topography (HRT) techniques. Among these techniques, terrestrial and airborne laser scanning (TLS and ALS) and Structure from Motion Multi-View Stereo (SfM-MVS, hereafter SfM) have proven to be effective and flexible, at various spatial and temporal scales $[27,28]$ revolutionizing digital elevation models (DEMs) resolution $[29,30]$ and data acquisition in mountain cryosphere investigations [23,31,32]. In particular, SfM has evolved into a valuable, safe, and cost-efficient technique to derive annual geodetic mass changes of small glaciers of similar quality compared to TLS or ALS techniques [32,33]. Moreover, terrestrial and aerial SfM surveys can be combined to overcome the main limits of both techniques [34]. In fact, the terrestrial approach can provide an accurate representation of complex surfaces [35] but its use is limited to small areas and it may poorly represent a homogeneous terrain. On the contrary, aerial surveys (e.g., using Unmanned Aerial Veicles-UAV) can cover wide areas quickly [36], but aerial-derived DEMs are not optimal in cases of steep or vertical terrains [37].

In this work, we present the results of a 13-year time series of high-resolution observations carried out on the Occidentale del Montasio Glacier, in the period from 2006 to 2019. The investigations were aimed at studying the behavior and climatic response of small glaciers fed by avalanches and 
covered by debris in their ablation area, in the context of Alpine glacier mass balance observations. The geodetic mass balance, surface dynamics and morphological adjustment have been determined by comparing multi-temporal sub-meter resolution DEMs surveyed by means of ALS, TLS, and groundand UAV-based SfM techniques.

\section{The Occidentale del Montasio Glacier}

The Occidentale del Montasio Glacier (called the "Montasio Glacier" hereinafter) is inventoried as IT4L00003005 in the World Glacier Inventory-WGI [38,39]. It is located in the Eastern European Alps (Italian Julian Alps), close to the border with Austria and Slovenia (Figure 1), where it lies at the base of the vertical northern walls of the Mount Jôf di Montasio (2754 m a.s.1.). It covers an area of $0.066 \mathrm{~km}^{2}$ (length $350 \mathrm{~m}$; maximum width $280 \mathrm{~m}$ ) and it is the lowermost Italian glacier (elevation ranging from 1860 to $2050 \mathrm{~m}$ a.s.l., median elevation at $1900 \mathrm{~m}$ a.s.l. and mean elevation at $1910 \mathrm{~m}$ a.s.l.).

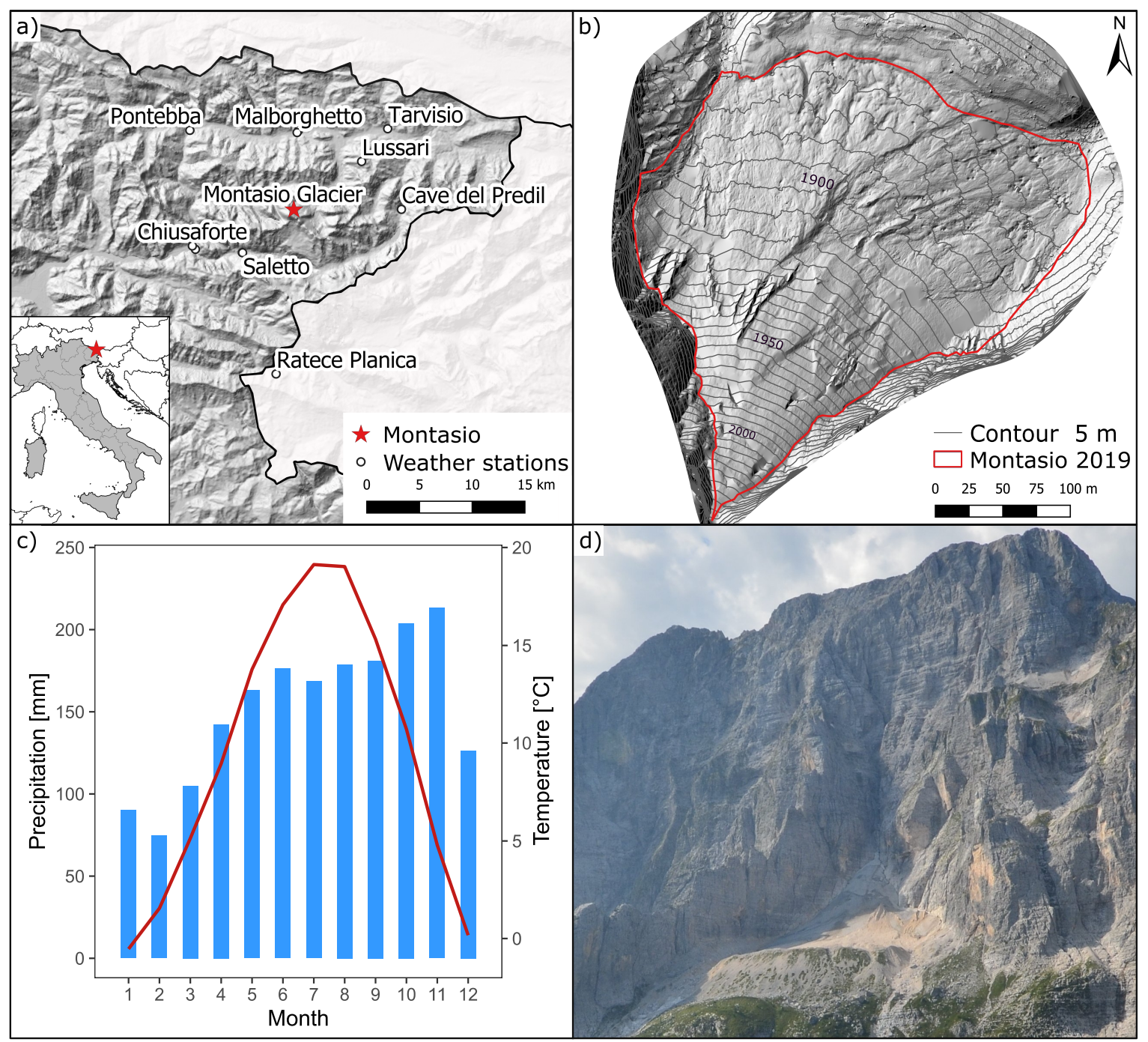

Figure 1. (a) Geographic setting of the Montasio Glacier and of the weather stations in the study area; (b) glacier topography over the shaded relief map of the high-resolution 2019 SfM survey; (c) monthly temperature and precipitation climatology in the period from 1960 to 2009 at the Pontebba weather station; (d) photo of the glacier and northern walls of the Mount Jôf di Montasio (Photo F. Cazorzi, 16 August 2012).

The glacier is characterized by a steep cone-shaped accumulation area, which is mainly nourished by winter avalanches, whereas the ablation area consists of a more gently sloped surface, entirely 
covered by a debris layer (Figure 2). The terminus is delimited by a moraine complex composed of juxtaposed ridges, built in different periods. The oldest ridge is dated to the Little Ice Age (LIA) maximum glacier expansion, whereas its inner ridges have been attributed to the beginning of the 20th century [17].



Figure 2. Photos of the Montasio Glacier taken from 2006 to 2019 at the end of the ablation season. Colored dots indicate reference points visible on the rock walls; the black line indicates the upper edge of the glacier.

A geophysical survey conducted in September 2010 pointed out that the average ice thickness along a longitudinal and a lower-transverse profile were $15 \mathrm{~m}$ and $8.5 \mathrm{~m}$, respectively, with maximum values of 22-24 $\mathrm{m}$ in the middle area [17]. The survey showed a heterogeneous layer composed by glacier ice, clasts, till, and flowing melt water at the glacier bed, and an average thickness of $\sim 2.5 \mathrm{~m}$ of the debris layer in the lower half of the glacier.

The 1960-2009 climatology at the Pontebba weather station (561 m a.s.1., $12 \mathrm{~km}$ north-east of the glacier) is characterized by a mean annual temperature of $9.9^{\circ} \mathrm{C}$. The coldest month is January with a mean temperature of $-0.5^{\circ} \mathrm{C}$, and the warmest month is July with a mean temperature of $19.1^{\circ} \mathrm{C}$. At the glacier's mean elevation, the annual temperature is $1.6^{\circ} \mathrm{C}$. The mean annual precipitation is $1814 \mathrm{~mm}$, with a monthly regime that shows a distinct winter minimum in February (75 mm) and a maximum in November (213 mm, Figure 1).

\section{Methods}

The mass balance and dynamics of the Montasio Glacier were investigated by means of high-resolution topographic surveys, performed on the glacier and its surroundings over a period from 2006 to 2019. The results have been successively analyzed in comparison with time series of meteorological variables related to glacier mass balance. 


\subsection{Topographic Surveys}

\subsubsection{Data Acquisition}

Topographic surveys were performed at annual intervals from 2010 to 2019, during the second half of September or in October (Table 1). Topographic data were acquired using TLS from 2010 to 2013, and SfM from 2014 to 2019. The two techniques were applied jointly in 2012 and 2013 for evaluating and confirming their interchangeability [32].

Table 1. Main characteristics of topographic surveys used in this study. Survey technology: ALS = Aerial Laser Scanning, TLS = Terrestrial Laser Scanning, SfM = Structure from Motion. Platform: $\mathrm{T}=$ terrestrial, $\mathrm{A}=$ aerial. Camera type: $\mathrm{C}=$ Canon EOS 5D Mark III, N = NIKON D5100, S = Sony Alpha 5000.

\begin{tabular}{cccccccccccc}
\hline Year & $\mathbf{2 0 0 6}$ & $\mathbf{2 0 1 0}$ & $\mathbf{2 0 1 1}$ & $\mathbf{2 0 1 2}$ & $\mathbf{2 0 1 3}$ & $\mathbf{2 0 1 4}$ & $\mathbf{2 0 1 5}$ & $\mathbf{2 0 1 6}$ & $\mathbf{2 0 1 7}$ & $\mathbf{2 0 1 8}$ & $\mathbf{2 0 1 9}$ \\
\hline Date & $13 / 09$ & $23 / 09$ & $29 / 09$ & $05 / 10$ & $26 / 09$ & $26 / 10$ & $20 / 10$ & $04 / 10$ & $10 / 10$ & $03 / 10$ & $01 / 10$ \\
Technology & ALS & TLS & TLS & TLS & TLS & SfM & SfM & SfM & SfM & SfM & SfM \\
Platform & A & T & T & T & T & T & T & T & T-A & T-A & T-A \\
Camera & - & - & - & - & - & C & N & N & S & S & S \\
DEM resolution (m) & 1.00 & 0.20 & 0.20 & 0.20 & 0.20 & 0.20 & 0.20 & 0.20 & 0.20 & 0.20 & 0.20 \\
\hline
\end{tabular}

The TLS surveys were performed using a Riegl LMS-Z620 from two scan positions located over the LIA terminal moraine as reported in Carturan et al. (2013) and in Piermattei et al. (2015) [17,32]. A GNSS (Global Navigation Satellite System) network has been set up with dual-frequency GPS/GLONASS receivers (Topcon HiPer PRO-Topcon Positioning Italy Srl, Ancona, Italy) to geo-reference the TLS surveys in the WGS84/UTM zone 33N (EPSG: 32633) reference system.

Photogrammetric survey methods evolved over the years, as well as cameras and GNSS used in surveys, in order to increase both the survey's quality and efficiency. The ground-based SfM surveys have been integrated with UAV aerial surveys since 2017 (Table 1). The georeferentiation and scaling of SfM models were based exclusively on natural targets identified from a TLS point cloud [32], and located over stable areas outside the glacier. In addition to these, artificial Ground Control Points (GCPs) were positioned on the glacier surface and surveyed using GNSS (Leica Zeno20) since 2017.

In order to extend the observation period before 2010, we included the ALS regional survey performed in September 2006 and made available by the Civil Protection Department of the Friuli Venezia Giulia Region.

\subsubsection{Data Processing and DEM Generation}

The raw point clouds collected with TLS were processed using the RiSCAN PRO (Riegl) and ArcGIS (ESRI) software in order to obtain georeferenced point clouds, which had a point density



The 2006 ALS point cloud had a significantly lower point density (1.63 pts $\mathrm{m}^{-2}$ on average) because it was acquired from an aerial platform located at a high distance above the glacier. We co-registered the ALS point cloud to the 2013 TLS point cloud, to optimize accuracy in glacier-change detection. We selected the 2013 TLS survey as a reference, among the four acquired using TLS, because of its highest quality. Stable areas outside the glacier were used as benchmarks for co-registration, which was carried out using the GRD-CoReg free software [40].

The SfM surveys were processed using the computer vision-based software PhotoScan (v. 1.4.3.6488 [41]-Agisoft LLC, St. Petersburg, Russia). The workflow for the generation of the dense point clouds is described in detail in $[32,33,36]$. The generated point clouds had a mean density of $100 \mathrm{pts} \mathrm{m}^{-2}$ and were co-registered to stable areas outside the glacier in the 2013 TLS survey, using the Iterative Closest Point (ICP) algorithm implemented in the OPALS software [42]. Co-registration was required to minimize the residual misalignment between point clouds generated in PhotoScan. 
Each ALS, TLS, and SfM point cloud was then converted to a Triangular Irregular Network (TIN) in ArcGIS, and finally transformed into DEMs with $0.2 \mathrm{~m}$ spatial resolution. Due to the lower point density, the 2006 ALS point cloud was transformed into a DEM with $1 \mathrm{~m}$ spatial resolution.

\subsection{Mass Balance Measurements and Calculations}

The geodetic mass balance was calculated annually differencing DEMs, and accounting for areal variations in glacier extent and different substrata (residual snow, firn, debris-covered ice). Owing to the ample interannual variations in the spatial coverage of these substrata, we could not assume an unchanged density structure of the glacier among consecutive surveys (i.e., Sorge's law [43]) as previously done by Carturan et al. (2013) [17] for the 2010-2011 balance year. Instead, we calculated an area-weighted mean density based on the spatial extent of different substrata, which was used for converting elevation changes obtained from DEMs into depths of water equivalent. In weighted mean density calculations, we used $0.650 \mathrm{~kg} \mathrm{~m}^{-3}$ for residual snow and $0.700 \mathrm{~kg} \mathrm{~m}^{-3}$ for firn, as obtained from direct snow pit measurements. We assigned a density of $0.900 \mathrm{~kg} \mathrm{~m}^{-3}$ to the debris-covered ice.

The annual extent of the substrata was mapped manually using oblique terrestrial and UAV photos, hill-shaded DEMs and DoDs (DEM of Differences). In the upper, debris-free area, the glacier perimeter was updated annually in a similar manner, whereas it was assumed to be unchanged in the lower part, due to the thick layer of debris that prevents the recognition of short-term fluctuations in glacier margins.

The AAR has been estimated as the ratio between the area covered by residual snow at the end of the ablation season and the total glacier area. It was not possible to calculate the ELA because the geodetic method does not provide the mass balance variation as a function of altitude, and therefore it was not possible to assess the mean elevation corresponding with zero mass balance.

\subsection{Glacier Dynamics}

Vertical and horizontal displacement rates were estimated using hill-shaded DEMs collected in 2010, 2013, 2017, and 2019, which were selected due to their highest quality among all the available surveys. The horizontal displacement was assessed by visual recognition of selected features in the debris-covered area of the glacier.

Horizontal displacement rates in meters per year were calculated using the formula reported in Ai et al. (2019) [44]:

$$
H h=365.25 \frac{\sqrt{\left(x_{e}-x_{i}\right)^{2}+\left(y_{e}-y_{i}\right)^{2}}}{\Delta t}
$$

where $x_{i}$ and $y_{i}$ are the coordinates of the first observation, $x_{e}$ and $y_{e}$ are the coordinates of the second observation, and $\Delta t$ is the time span in days intercurred.

Vertical displacement rates in meters per year were calculated as:

$$
V h=365.25 \frac{d Z-d Z_{\text {exp }}}{\Delta t}
$$

where $d Z$ is the total elevation change between the two surveys $\left(\bar{z}_{\mathrm{e}}-\bar{z}_{\mathrm{i}}\right)$ and $d Z_{\text {exp }}$ is the expected vertical movements calculated based on mean slope angle (for a schematic representation of the displacement components see Bosson and Lambiel (2016) [22]). The mean slope angle was calculated for each investigated point using the initial DEM and averaging the slope within a radius of $5 \mathrm{~m}$. Similarly, the initial mean elevation $\left(\bar{z}_{\mathrm{i}}\right)$ and ending mean elevation $\left(\bar{z}_{\mathrm{e}}\right)$ were estimated averaging the DEM elevation with a radius of $5 \mathrm{~m}$.

\subsection{Meteorological Data Series}

The meteorological conditions in the analyzed period were compared to longer time series of meteorological variables related to glacier mass balance, for calculating anomalies and highlighting 
possible long-term trends. We analyzed air temperature, precipitation, and fraction of solid precipitation (i.e., the nivometric coefficient) in the ablation (May to October) and the accumulation (November to April) seasons, comparing the period from 2010 to 2019 with the 1960-2009 climatology.

Series of air temperature and precipitation data at the weather station of Pontebba (Figure 1) were used in the analyses. We used this station because of its proximity to the Montasio Glacier, and for the high-quality and length of meteorological records. Calculations of monthly and seasonal data started mainly from daily measurements; hourly measurements have been used when available (Table 2). Quality check, homogenization, and gap-filling required the use of data from several other stations, listed in Table 2. The procedures used are in line with the guidelines from the World Meteorological Organization [45] and are detailed in Baldassi (2010) [46].

The obtained daily temperatures have been extrapolated at the mean elevation of the Montasio Glacier (1910 m a.s.l.), using monthly variable vertical gradients calculated over the period from 1999 to 2010 between the Pontebba and Lussari weather stations. The extrapolated temperature served for discriminating between liquid and solid precipitation (daily threshold temperature $=2{ }^{\circ} \mathrm{C}$ ), required for the estimation of the nivometric coefficient at the glacier's mean elevation. We decided to avoid extrapolating precipitation in a way similar to air temperature, because the study area is affected by large horizontal and vertical gradients [47], which would require high-quality measurements of (gauge-corrected) precipitation at high elevation for their estimation. Because these measurements are not available, we assumed that quality-checked precipitation data at low altitude are more suitable for our analyses than extrapolations subject to a high uncertainty.

Table 2. Characteristics of the weather stations and meteorological data used in this study.

\begin{tabular}{|c|c|c|c|c|c|}
\hline Station Name & $\begin{array}{c}\text { Provider } \\
\text { Institution }\end{array}$ & $\begin{array}{l}\text { Measured } \\
\text { Variable }^{2}\end{array}$ & $\begin{array}{c}\text { Frequency }^{3} \\
\text { (Technique }^{4} \text { ) }\end{array}$ & Working Period & Elevation (m a.s.1.) \\
\hline Saletto (Chiusaforte) & RMR & $\mathrm{T}, \mathrm{P}$ & $\mathrm{H}(\mathrm{A})$ & $2003-$ & 506 \\
\hline Saletto & SIMN & Tx, Tn & $\mathrm{D}(\mathrm{M})$ & 1919-2013 & 507 \\
\hline Saletto & SIMN & $\mathrm{P}$ & $\mathrm{D}(\mathrm{M})$ & 1938-2013 & 507 \\
\hline Pontebba & SIMN & Tx, Tn & $\mathrm{D}(\mathrm{M})$ & 1915-2013 & 561 \\
\hline Pontebba & SIMN & $\mathrm{P}$ & $\mathrm{D}(\mathrm{M})$ & 1926-2013 & 561 \\
\hline Pontebba & RMR & $\mathrm{T}, \mathrm{P}$ & $\mathrm{H}(\mathrm{A})$ & $2003-$ & 568 \\
\hline Innsbruck & ZAMG & $\mathrm{T}, \mathrm{P}$ & $\mathrm{D}$ & 1877-2004 & 577 \\
\hline Malborghetto & SIMN & Tx, Tn & $\mathrm{D}(\mathrm{M})$ & 1986-2013 & 720 \\
\hline Malborghetto & SIMN & $\mathrm{P}$ & $\mathrm{D}(\mathrm{M})$ & 1921-2013 & 720 \\
\hline Malborghetto & RMR & $\mathrm{T}, \mathrm{P}$ & $\mathrm{H}(\mathrm{A})$ & $2004-$ & 733 \\
\hline Tarvisio & RMR & $\mathrm{T}, \mathrm{P}$ & $\mathrm{H}(\mathrm{A})$ & 1999- & 794 \\
\hline Ratece Planica & ECA\&D & $\mathrm{T}, \mathrm{P}$ & $\mathrm{D}$ & 1961-2013 & 864 \\
\hline Cave del Predil & RMR & $\mathrm{T}, \mathrm{P}$ & $\mathrm{H}(\mathrm{A})$ & $2006-$ & 900 \\
\hline Cave del Predil & SIMN & Tx, Tn & $\mathrm{D}(\mathrm{M})$ & 1948-2013 & 904 \\
\hline Cave del Predil & SIMN & $\mathrm{P}$ & $\mathrm{D}(\mathrm{M})$ & 1923-2013 & 904 \\
\hline Lussari & RMR & $\mathrm{T}, \mathrm{P}$ & $\mathrm{H}(\mathrm{A})$ & 1999-2017 & 1760 \\
\hline
\end{tabular}

${ }^{1}$ Provider institutions: SIMN = Servizio Idrografico e Mareografico Nazionale; RMR = Rete Meteorologica Regionale Friuli Venezia Giulia; ZAMG = Zentralanstalt für Meteorologie und Geodynamik; ECA\&D = European Climate Assessment and Dataset) $[48,49] .{ }^{2}$ Measured variables: $\mathrm{T}=$ air temperature, $\mathrm{Tx}=$ maximum temperature, $\mathrm{Tn}=$ minimum temperature, $\mathrm{P}=$ rainfall. ${ }^{3}$ Frequency: $\mathrm{D}=$ daily, $\mathrm{H}=$ hourly. ${ }^{4}$ Technique: $\mathrm{M}=$ manual, $\mathrm{A}=$ automatic.

\section{Results}

\subsection{Elevation Change and Mass Balance}

The Montasio Glacier experienced significant interannual variability in surface elevation and mass balance in the period from 2006 to 2019. The middle and upper parts of the glacier showed the largest variability whereas the lower part, covered by thick debris, underwent smaller changes (Figure 3). Conditions favoring thickening prevailed from 2006 to 2014 (Table 3, Figure 4), with a cumulated average elevation change of $+4.38 \mathrm{~m}$, which corresponds to a mass balance rate of $+0.42 \mathrm{~m}$ w.e. year $^{-1}$. Thinning became dominant after 2014, with a mass balance rate averaging $-0.92 \mathrm{~m}$ w.e. year ${ }^{-1}$ from 2015 to 2019 and a cumulated average elevation change of $-5.84 \mathrm{~m}$. If the entire period from 2006 to 
2019 is considered, the average mass balance rate of the Montasio Glacier was -0.07 m w.e. year ${ }^{-1}$. The Montasio Glacier was much closer to balanced-budget conditions than the nine "reference glaciers" of the European Alps (Sarennes, Saint Sorlin, Gries, Silvretta, Hintereis, Kesselwand, Vernagt, Careser and Sonnblick, WGMS [50,51]), whose mass balance rate averaged $-1.42 \mathrm{~m}$ w.e. year ${ }^{-1}$ in the same period (Table 3).

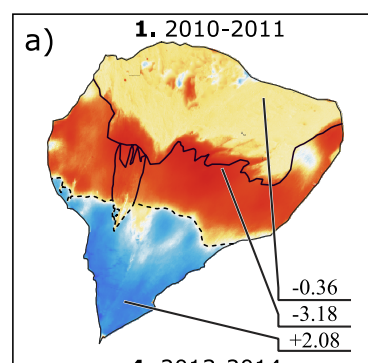

4. $2013-2014$

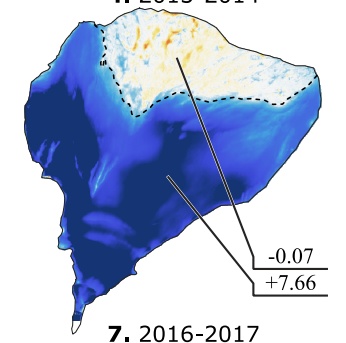

7. 2016-2017

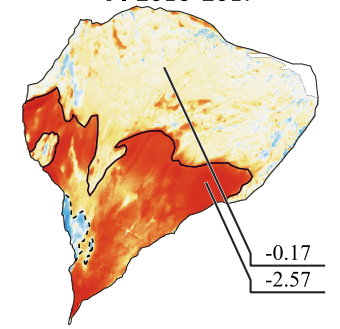

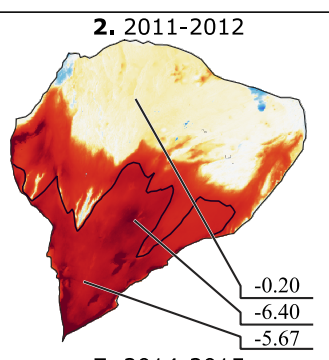

5. $2014-2015$

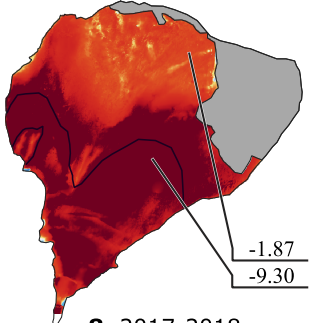

8. $2017-2018$



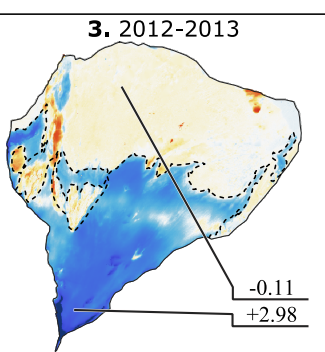

6. $2015-2016$



9. $2018-2019$

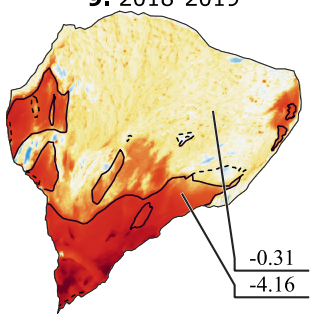

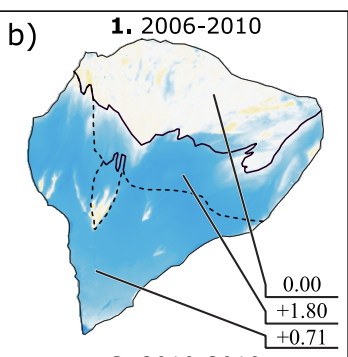

2. $2010-2019$

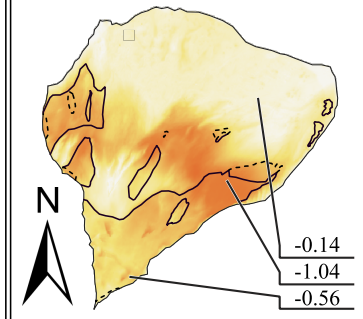

Elevation change $\left[\mathrm{m} \mathrm{yr}^{-1}\right]$

$\square$ NA $\square-1.5 \square 1.5$

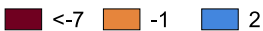

\begin{tabular}{l}
$-6 \quad \square-0.5 \square 3$ \\
\hline-5
\end{tabular}

$\square-5 \square 0 \quad \square 5$

$-3 \square 0.5 \square 6$
-2

$\square-2 \square 1 \square>7$

- Firn line -.... Snow line

$\begin{array}{lllll}0 & 50 \quad 100 \quad 150 \quad 200 \mathrm{~m}\end{array}$

Figure 3. Annual elevation change rate for (a) individual years and (b) two sub-periods.

Table 3. Comparison of annual balances and Accumulation Area Ratios (AARs) measured on the Montasio Glacier with the geodetic method, and on nine alpine reference glaciers (Sarennes, Saint Sorlin, Gries, Silvretta, Hintereis, Kesselwand, Vernagt, Careser, and Sonnblick) with the glaciological method. The mass balance data for the reference glaciers have been retrieved from Zemp et al. (2020) [50], unless otherwise specified.

\begin{tabular}{|c|c|c|c|c|c|c|}
\hline \multirow[b]{2}{*}{ Period $^{1}$} & \multicolumn{3}{|c|}{ Montasio Occidentale Glacier (Geodetic Balance) } & \multicolumn{3}{|c|}{ Alpine Reference Glaciers (Glaciological Balance) } \\
\hline & $\begin{array}{l}\text { Annual Balance } \\
\left(\mathrm{m} \text { w.e. } \text { Year }^{-1} \text { ) }\right.\end{array}$ & $\begin{array}{c}\text { Error } \\
\left(\mathrm{m} \text { w.e. } \text { Year }^{-1}\right)\end{array}$ & AAR & $\begin{array}{l}\text { Annual Balance } \\
\text { (m w.e. Year-1) }\end{array}$ & $\begin{array}{l}\text { Standard Deviation } \\
\left(\mathrm{m} \text { w.e. } \text { Year }^{-1}\right)\end{array}$ & $\begin{array}{c}\text { AAR } \\
\text { (Observations) }\end{array}$ \\
\hline $2006-2010$ & 0.52 & 0.05 & 1 & -1.32 & 0.65 & \\
\hline 2010-2011 & -0.25 & 0.09 & 0.22 & -2.01 & 1.08 & $0.11(7)$ \\
\hline 2011-2012 & -2.18 & 0.10 & 0.00 & -1.76 & 0.68 & $0.08(7)$ \\
\hline $2012-2013$ & 0.50 & 0.05 & 0.41 & -0.55 & 0.50 & $0.44(7)$ \\
\hline 2013-2014 & 3.18 & 0.08 & 0.74 & -0.50 & 0.78 & $0.52(7)$ \\
\hline 2014-2015 & -3.96 & 0.34 & 0.00 & -2.12 & 0.80 & $0.07(7)$ \\
\hline $2015-2016$ & 0.40 & 0.38 & 0.19 & -1.06 & 0.42 & $0.20(7)$ \\
\hline $2016-2017$ & -0.64 & 0.13 & 0.02 & -2.04 & 0.69 & $0.04(7)^{2}$ \\
\hline 2017-2018 & 0.46 & 0.10 & 0.36 & -1.77 & $0.28^{2,3}$ & $0.08(5)^{2,4,5,6}$ \\
\hline 2018-2019 & -0.83 & 0.11 & 0.02 & -1.37 & $1.00^{2,3}$ & $0.25(5)^{2,4,5,6}$ \\
\hline $2006-2019$ & -0.07 & 0.01 & / & -1.42 & 0.62 & / \\
\hline
\end{tabular}

${ }^{1}$ Annual average values are reported on multi-year periods. ${ }^{2}$ Sonnblickkees data were kindly provided by B. Zagel [52]. ${ }^{3}$ Saint Sorlin Glacier data have been downloaded from the GLACIOCLIM website [53]. ${ }^{4}$ Vernagtferner data have been downloaded from the Bayerische Akademie der Wissenschaften website [54]. ${ }^{5}$ Hintereis ferner and Kesselwandferner data from Rotach M. and Prinz R. (2019) [55]. ${ }^{6}$ Careser Glacier data from Baroni et al. (2019) [56]. 


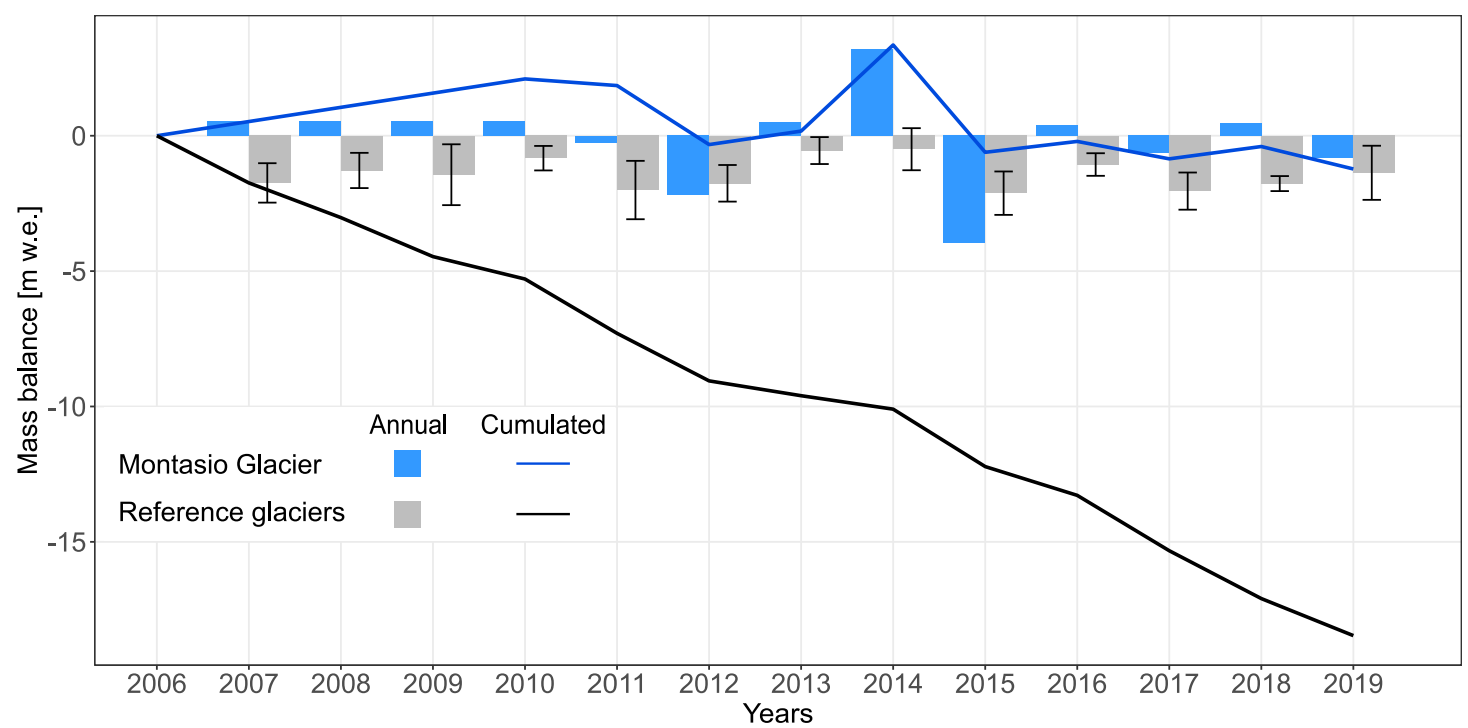

Figure 4. Annual and cumulated geodetic mass balance on the Montasio Glacier compared with the average glaciological annual and cumulated balance of nine reference glaciers in the European Alps, in the period from 2006 to 2019.

The large interannual variability in elevation change and mass balance was mostly related to the amount and extent of the snow cover at the end of the ablation season. In favorable years, the middle and upper parts of the glacier developed a snow and firn cover that was several meters thick (Figures 2 and 3); on the contrary, in unfavorable years, the winter snow vanished almost completely, and the firn of previous years was rapidly melted or buried by debris. The AAR was strongly related to mass balance $(r=0.94$ considering years with AAR $>0.05)$. From the linear regression between $\mathrm{AAR}$ and mass balance, we can estimate a balanced-budget $\mathrm{AAR}_{0}$ close to 0.30 . Coherent with mass balance behavior, the firn-covered area expanded between 2006 and 2014, and considerably shrunk afterwards (Figures 3 and 5). The year-to-year variability in mass balance was directly proportional to the extent of the firn area.

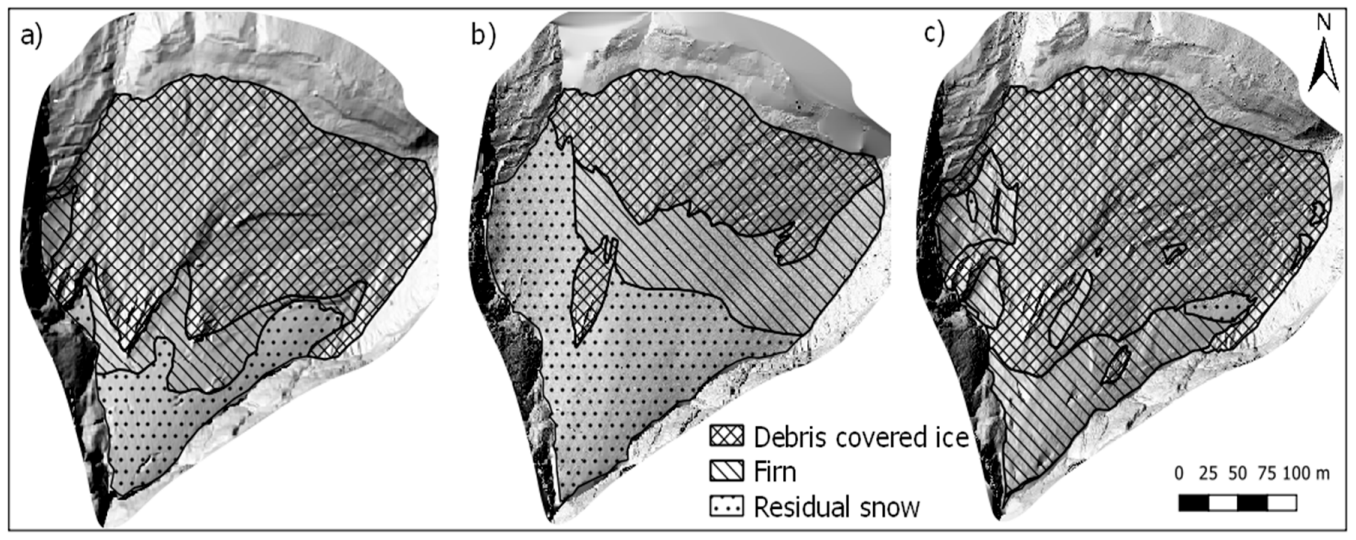

Figure 5. Spatial extent of substrata covering the Montasio Glacier at the end of the ablation season in three different years: (a) 2006, (b) 2010, and (c) 2019.

Compared to annual changes (Figure 3), the spatial pattern of the cumulated elevation changes from 2006 to 2019 (Figure 6) looks less dependent on snow and firn cover, and more related to the deposition and spatial reworking of the debris cover. In particular, there are small thickening areas ("a" in Figure 6) that correspond to debris flow deposits in the middle and lower parts of the glacier, and a larger thickening area (b) in the middle-upper part, which is the deposit of a landslide fallen on the glacier in 2016. The areas where surface lowering is homogeneous indicate snow and firn melt 
(c) or ice melt below a thick debris cover (d) in the lower zone; areas showing inhomogeneous lowering represent gully erosion (e), and small sinkholes (f).

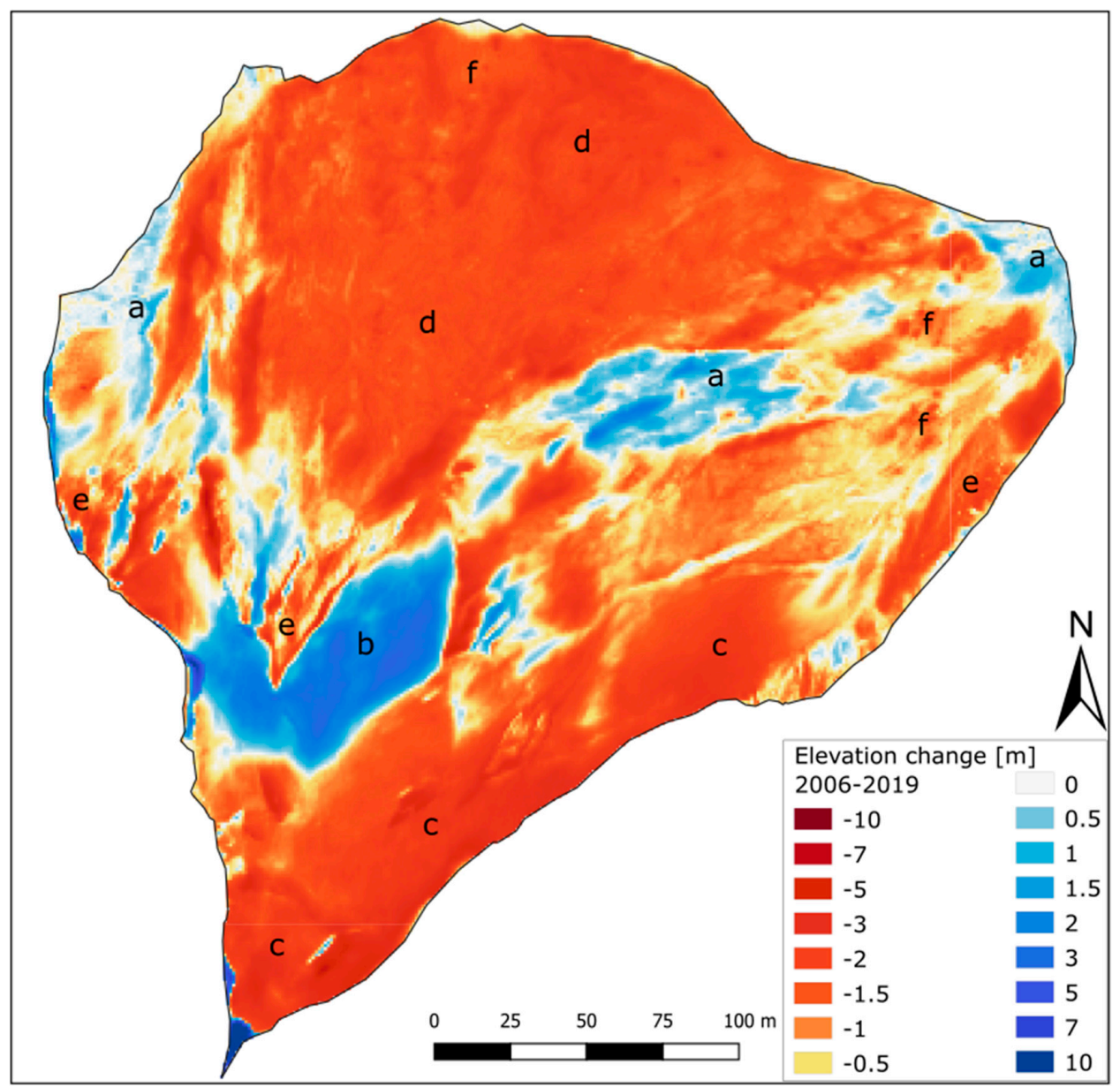

Figure 6. Elevation change cumulated in the period from 2006 to 2019 on the Montasio Glacier. The letters represent areas described in Section 4.1.

\subsection{Glacier Dynamics}

The horizontal surface displacement mapped in the period from 2010 to 2019 shows a divergent pattern (Figure 7) that confirms the findings of Carturan et al. (2013) [17]. The movement indicates internal deformation and flow, rather than a mass movement, which, together with mass transfer from the upper accumulation area to the lower ablation area, differentiates the Montasio Glacier from glacierets or ice patches [57].

Horizontal velocities are lowest in the central part of the glacier front, were subsidence is highest (Figure 7). The frontal moraine clearly represents an obstacle to glacier flow, which diverges and tends to be conveyed laterally, towards breaches opened by water erosion at the eastern and western edges of the moraine. Surface and bedrock slope are highest in the eastern part of the glacier front [17], and therefore surface velocities are maximal in this part of the glacier, which is also characterized by vertical displacements closer to zero.

Analyses focused in three different sub-periods indicate a tendency to deceleration, with decreasing horizontal displacement (Figure 8). The slowdown was remarkable after 2017 in the western part, which decelerated from 0.13 to $0.05 \mathrm{~m}$ year $^{-1}$, whereas it was less significant in the eastern part. Vertical velocities tended towards less negative values, particularly between 2013 and 2017 and in the eastern part. In the last sub-period this tendency looks exhausting or even reversing. 




Figure 7. Displacement rates in the period from 2010 to 2019. Arrow lengths show horizontal displacement, whereas colors show vertical displacement. The arrow length used in this image is arbitrary and does not display the real horizontal cumulated displacement.

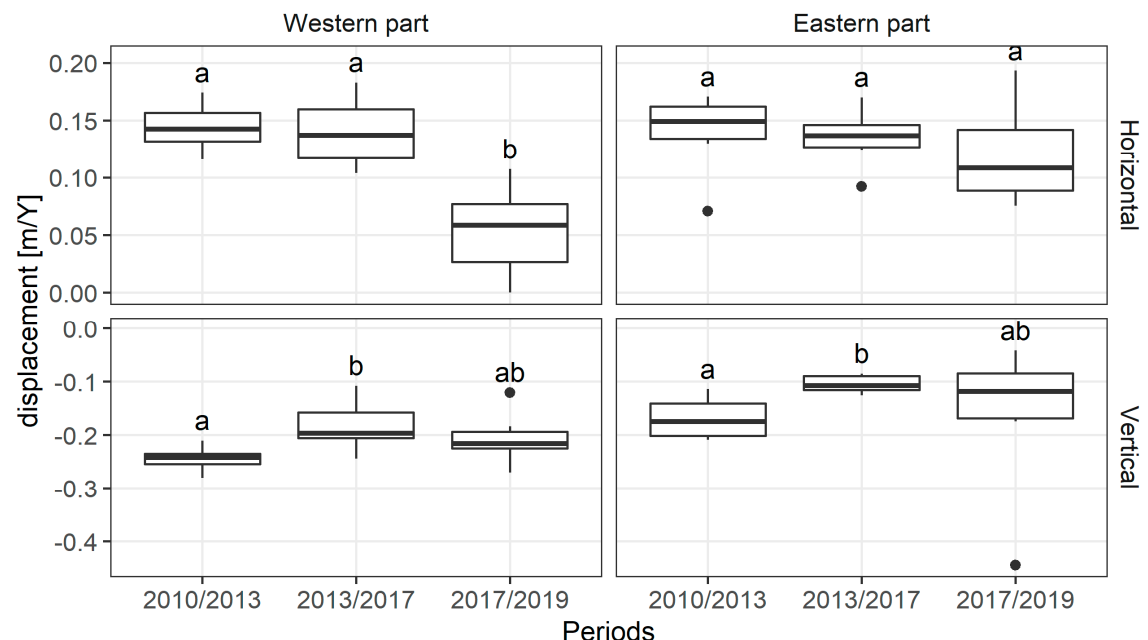

Figure 8. Horizontal and vertical displacement rates in the three sub-periods 2010-2013, 2013-2017, and 2017-2019. The letters above boxplots " $a$ " and " $b$ " indicate which groups of samples are statistically similar (those sharing a common letter) and statistically different (those not sharing a common letter) according to the Wilcoxon test ( $p$-values $<0.05)$. 


\subsection{Meteorological Conditions}

The long-term trend of the air temperature extrapolated with monthly gradients at the mean elevation of the Montasio Glacier is clearly positive, both in the accumulation and ablation season (Figure 9a). According to the Mann-Kendall test, the trend is highly significant $(p<0.001)$ and can be quantified in $0.57^{\circ} \mathrm{C} /$ decade for the ablation season, and $0.53{ }^{\circ} \mathrm{C} /$ decade for the accumulation season. In the last decade the mean temperature in the ablation and accumulation season was $1.63{ }^{\circ} \mathrm{C}$ and $1.79{ }^{\circ} \mathrm{C}$ warmer than the 50-year mean, respectively (Table 4). We also point out that the ablation season is currently about $3{ }^{\circ} \mathrm{C}$ warmer than it was in the period from 1960 to 1980 , when glacier advance occurred in the European Alps [58]. The warming trend began in the 1980s and looks to continue.



Figure 9. Time series of: (a) mean temperature of accumulation and ablation seasons extrapolated at the glacier's mean elevation; (b) seasonal nivometric coefficient (NC) at the glacier's mean elevation; total precipitation amount of (c) accumulation season, and (d) ablation season, fractioned into solid and liquid portions at the glacier's mean elevation.

Table 4. Accumulation and ablation season temperature and precipitation in the 2010-2019 decade, compared to the 50-year means. Rain and snow fractions of total precipitation are also compared. Temperature is extrapolated at the mean elevation of the Montasio Glacier applying monthly-variable gradients to the Pontebba weather station data. Precipitation data from the same station are not extrapolated at the glacier's elevation, but are partitioned into liquid and solid fractions using extrapolated temperature.

\begin{tabular}{ccccccc}
\hline & \multicolumn{3}{c}{ Accumulation Season (November-April) } & \multicolumn{3}{c}{ Ablation Season (May-October) } \\
\hline & $\mathbf{1 9 6 0 - 2 0 0 9}$ & $\mathbf{2 0 1 0 - 2 0 1 9}$ & $\mathbf{2 0 1 0 - 2 0 1 9}$ Anomaly & $\mathbf{1 9 6 0 - 2 0 0 9}$ & $\mathbf{2 0 1 0 - 2 0 1 9}$ & $\mathbf{2 0 1 0 - 2 0 1 9}$ Anomaly \\
\hline Temperature $\left({ }^{\circ} \mathrm{C}\right)$ & -3.89 & -2.10 & +1.79 & 6.60 & 8.23 & +1.63 \\
Precipitation $(\mathrm{mm})$ & 750 & 743 & $-1 \%$ & 1072 & 1028 & $-4 \%$ \\
Rain $(\mathrm{mm})$ & $59(8 \%)$ & $146(20 \%)$ & $+147 \%$ & $808(75 \%)$ & $836(81 \%)$ & $+3 \%$ \\
Snow $(\mathrm{mm})$ & $692(92 \%)$ & $597(80 \%)$ & $-14 \%$ & $263(25 \%)$ & $192(19 \%)$ & $-27 \%$ \\
\hline
\end{tabular}

The total precipitation in the accumulation and ablation season does not display long-term trends. This lack of trend can be appreciated visually from Figure 9c,d, and is confirmed by the Mann-Kendall test, which indicates that trends are not significant $(p>0.05)$. Total precipitation during the warm semester is $1072 \mathrm{~mm}$ on average, which is $42 \%$ larger than the average total precipitation amount during cold semesters. In the period analyzed in this work, winters with abundant snowfall (e.g., 2009, 2014, and 2018) alternated with winters with scarce precipitation (e.g., 2012, 2015, and 2016). 
Remarkable consequences in the glacier's mass balance are expected from increasing temperature, not only for the augmented melt but also for the decreased fraction of solid precipitation (the so-called nivometric coefficient, NC). As expected from temperature trends, both the accumulation and ablation seasons show decreasing NCs, with statistically significant trends $(p<0.05)$. After a period of stability, the NCs started to decrease in the early 1980s for the ablation season, and in the mid-1990s for the accumulation season. The annual NC decreased from $52 \%$ to $45 \%$ comparing the two periods 1960-2009 and 2010-2019. The largest variations are observed in spring and autumn, with the months of May, October, and November that have NCs already decreased, or just above, the $50 \%$ level (Figure 10). This transition of solid towards liquid precipitation is causing a decrease in the length of the accumulation season and a corresponding increase in the length of the ablation season. This transition is even more remarkable if one considers that the most affected months correspond with the annual maxima in precipitation.

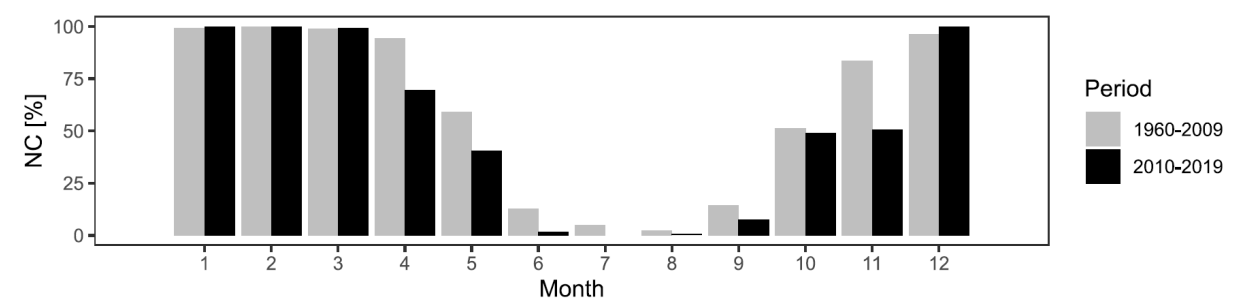

Figure 10. Comparison of the 2010-2019 average monthly Nivometric Coefficient (NC) calculated at the glacier's mean elevation with the 50-year average between 1960 and 2009.

\section{Uncertainty Assessment}

The accuracy of DEMs used in this work was assessed over stable areas in proximity to the glacier, calculating elevation differences between individual DEMs and the reference 2013 TLS DEM (Section 3.1.2). The mean of elevation differences ranges from -0.24 to $+0.08 \mathrm{~m}$, and averages -0.01 $\mathrm{m}$. The standard deviation of elevation differences ranges from 0.04 to $0.38 \mathrm{~m}$, with a mean value of $0.17 \mathrm{~m}$ (Table 5).

Table 5. Statistics of elevation differences calculated among individual DEMs and the reference 2013 TLS DEM over stable area in proximity to the glacier.

\begin{tabular}{ccc}
\hline DEM (Year) & Mean & St Dev \\
\hline 2006 & -0.01 & 0.31 \\
2010 & -0.24 & 0.04 \\
2011 & 0.08 & 0.11 \\
2012 & 0.04 & 0.06 \\
2013 & - & - \\
2014 & -0.09 & 0.10 \\
2015 & 0.00 & 0.38 \\
2016 & 0.02 & 0.18 \\
2017 & 0.04 & 0.16 \\
2018 & 0.06 & 0.15 \\
2019 & 0.04 & 0.16 \\
\hline Mean & -0.01 & 0.17 \\
\hline
\end{tabular}

The accuracy in geodetic mass balance calculations was evaluated comparing pairs of consecutives surveys, and was assessed over stable areas in proximity to the glacier, using the same procedure described above for individual DEMs. The standard deviation of elevation differences ranges from 0.06 to $0.47 \mathrm{~m}$, (mean value of $0.20 \mathrm{~m}$ ), which, multiplied by the density used in mass balance calculations, yields a range between 0.05 and $0.38 \mathrm{~m}$ w.e. year $^{-1}$ in geodetic mass balance calculations for single years (mean value of $0.15 \mathrm{~m}$ w.e. year ${ }^{-1}$ ). The mean elevation difference in stable areas ranged between -0.49 and $+0.32 \mathrm{~m}$ (mean value of $-0.01 \mathrm{~m}$ ), and was removed from the raw elevation change calculated 
in the glacier area, prior to mass balance calculations. The residual error is generally smaller than 0.10 m w.e. year $^{-1}$ (Table 3), with the exception of the 2015 and 2016 mass balance years. The larger error in these two years is due to the 2015 SfM DEM, which is affected by a higher uncertainty and a lower spatial coverage caused by the presence of recent snow at the time of the SfM survey (Figure 2).

In this work we have compared mass balance results obtained using the geodetic and the glaciological methods (Table 3, Figure 4). Even if the two methods can give rather different results at the local scale [59], the geodetic method is widely used in glacier-wide reanalyses and validation of mass balance series obtained with the glaciological method [60], and for assessments of glacier mass balance at the regional or mountain-range scale [7,8,61,62]. Our comparison serves to highlight possible macro differences between the response of the Montasio Glacier and the average response of glaciers in the European Alps, which far outweigh discrepancies due to the measurement methods.

The uncertainty in surface velocities was estimated evaluating the residual displacement of test points located on stable terrain outside the glacier. The residual errors in horizontal displacements are $0.03,0.04$, and $0.07 \mathrm{~m}_{\text {year }}{ }^{-1}$ for the periods 2010-2013, 2013-2017, and 2017-2019, respectively. Corresponding errors for the vertical component of displacements are $-0.04,-0.04$, and $0.05 \mathrm{~m}^{2} \mathrm{yr}^{-1}$.

The directional error looks random and not systematic (Figure 7), with the possible exception of a small area of the frontal moraine, in contact with the glacier and possibly in active deformation due to the melt out of its ice core. The surface displacement could not be assessed in the upper part of the glacier, due to the presence of snow and firn and due to the absence of detectable features (e.g., crevasses, seracs, and moulins).

The exact position of the lower margins of the glacier is hard to establish, because of the thick debris mantle that covers the ablation area. For this reason, it is not possible to map the front variations, even at the decadal time scale, and we decided to keep fixed the lower margin of the glacier because there were no clear indications of advance or retreat. Moreover, the local morphology and the latest DoDs (Figure 3) suggest that the glacier front is stationary. For the same reasons we avoided analyzing changes in glacier area, which have been of minor importance and limited to the upper accumulation area.

The homogeneity tests revealed that the temperature data series of Pontebba is of good quality, with only two short inhomogeneous periods: The first between 1 June 1984 and 31 January 1987 (correction applied $-0.70{ }^{\circ} \mathrm{C}$ ), and the second between 1 January 2017 and 31 December 2019 (correction applied $+0.42{ }^{\circ} \mathrm{C}$ ). The detected inhomogeneities in the precipitation series were smaller than $5 \%$, and therefore we considered them negligible and assumed homogeneous the entire 60-year period analyzed.

\section{Discussion}

The results of this study provide quantitative confirmation to our first observations on the current peculiar behavior of the Montasio Glacier, and on the hypothesized relationship between atmospheric changes and glacier response, based on preliminary investigations conducted between 2009 and 2011 [17]. The comparison with the sample of Alpine reference glaciers, in the period from 2006 to 2019 , clearly shows how the Montasio Glacier has been much less impacted by the present warm phase, at least until now (Figure 4, Table 3). Even taking into consideration the possible underestimation of alpine-wide mass balance using few reference glaciers [63], the mass loss rate of the Montasio Glacier

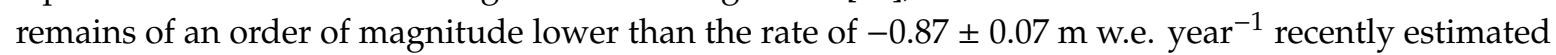
for all the glaciers in the Alps and Pyrenees, in the period from 2006 to 2016 [64].

In the highly scattered response of smaller glaciers to the climatic conditions of the last decades, the Montasio Glacier likely stands among ice bodies that are closer to balanced-budget conditions, taking advantage of a lower climatic sensitivity and/or negative feedbacks during deglaciation. Similar results showing an increasing control of local topography, and even a possible evolution towards steady-state conditions, have been reported by Carrivick et al. (2015) [65] for the Eastern Alps, Colucci (2016) [66] for the Julian Alps, and Scotti and Brardinoni (2018) [67] for the Val Viola in the Central Alps. 
The possible survival of avalanche-fed glaciers at low elevation to substantial atmospheric warming has been also suggested by Huss and Fischer (2016) [3], who modelled the climatic sensitivity of 1133 very small glaciers in the Swiss Alps. Outside the European Alps, similar results have been found, for example, by Dahl and Nesje (1992) [68] in Western Norway, and Debeer and Sharp (2009) [13] for the Canadian Rockies. Other studies have reported a contrasting behavior, with the smallest glaciers showing the highest vulnerability e.g., [9,69-71]. However, these results are averaged over a large number of small glaciers, with characteristics that are different from the Montasio Glacier. Interesting results have been reported by Bhambri et al. (2011) [72], who documented low area loss rates between 1968 and 2006 for glaciers having the lowest mean elevation in the Garhwal Himalaya, India. This suggests that the same factors enabling glacier existence at low elevation (shadowing, enhanced snow accumulation, debris cover, or their combinations) are possibly responsible of a smaller imbalance in the analyzed period.

The presented series of annual balances, quite rare for this type of glaciers, is now sufficiently long to investigate quantitatively the role of different climatic variables in the glacier's mass balance. The high variability of meteorological conditions in the investigated period (Figure 9) helped in this regard. A Spearman's correlation analysis between annual balance and annual/seasonal meteorological variables (air temperature, total/liquid/solid precipitation, and NCs), suggests that the annual amount of solid precipitation is a major control on mass balance $(r=0.88, p<0.005)$, followed by the solid precipitation amount in the accumulation season $(\mathrm{r}=0.73, p<0.05)$ and by the total amount of precipitation in the accumulation season $(\mathrm{r}=0.68, p<0.05)$. The mean temperature in the ablation season is not significantly correlated with mass balance $(r=-0.52, p=0.15)$. These results highlight the importance of snow accumulation for this avalanche-fed and heavily debris-covered glacier, not only in the accumulation season, but also in the months of May and October, which regulate the length of the ablation period.

The high sensitivity to snow accumulation is remarkable, especially in periods of rapid deglaciation, when mass balance generally correlates extremely well with summer temperature and shows no correlation with winter accumulation [73]. This strong dependence on solid precipitation is related to the high "avalanche ratio" (i.e., the ratio between the total area susceptible to avalanche, which is defined as slopes $>30^{\circ}$ leading directly onto the glacier, and the total glacier area [74]), which is 2.9 for the Montasio Glacier. This high ratio leads to a considerable increase in snow accumulation on the glacier surface, which can be estimated in about $300 \%$ compared to sites at the same elevation, unaffected by avalanches [17]. Our observations indicate that the glacier is primarily fed by frequent and small avalanches of loose snow, which accumulate mostly in the upper half of the glacier, thereby potentially doubling the avalanche ratio. The concentration of large amounts of snow in a small area has a twofold effect. The first is a reduction of the contact surface between snow and atmosphere, where the largest part of ablation takes place. The second effect is a manifold multiplication of the snow accumulation anomaly, compared to areas unaffected by avalanches. A solid precipitation anomaly of $+0.1 \mathrm{~m}$ w.e., for example, becomes $+0.4 \mathrm{~m}$ w.e. ( $+0.7 \mathrm{~m}$ considering only the upper half of the glacier), thus representing a relevant energy sink for ablation processes compared to areas without snow redistribution.

These considerations are valid also for negative precipitation anomalies and provide a key to the interpretation of the high sensitivity of this glacier to precipitation variability and accumulation processes, and of the lower sensitivity to air temperature and ablation processes. Besides air temperature variability, the summer ablation is largely dependent on the extent and thickness of the firn cover. In case of warm summers, a thick and widespread firn cover exposes the glacier to large mass loss, as occurred in 2015 after the highly positive 2014 mass balance year (Figures 3 and 4). Once the firn is depleted, such as in the last four years, the 2-3 m thick debris mantle that covers the underlying ice strongly limits ablation, and significantly dampens the inter-annual variability of mass balance and its sensitivity to air temperature. In the observed period, the best example for this behavior came from 2018, when the mass balance was slightly positive in spite of a very warm ablation season 
(the warmest since 1960). The thick avalanche deposits due to the above-average winter snowfalls (Figure 9), concentrated in a small accumulation area (Figure 3), slightly exceeded the mass losses in the ablation area, which were mitigated by: (i) the small extent of the 2017 firn area, exposed to ablation for a short period, and (ii) the debris insulation over a large portion of the glacier (Figures 2 and 3). This mass balance year highlights also why the glacier currently exhibits such a low balanced-budget $\operatorname{AAR}\left(\mathrm{AAR}_{0} \sim 0.30\right)$.

The glacier entered a phase of prevailing negative mass balance after 2014, when there was a gradual expansion of the area covered by debris (Figures 2 and 5), caused by the shrinking of the accumulation area and by the surface accumulation of debris contained in firn, following melt. In addition, we observed the formation of new deposits of fine-grained debris in the upper half of the glacier, caused by rockfalls. In 2016 one of these events occurred at the beginning of the melt season, covering a considerable portion of the glacier (see the positive elevation changes in the upper half of the glacier in Figure 3) and leading to the incorporation of firn lenses in the glacier body. The alternating layers of snow, firn, and debris retrieved in the upper zone of the glacier by the geophysical investigations carried out in 2010 [17] likely originate from events similar to this one observed in 2016.

Overall, the sediment budget of the glacierized area looks positive. Debris supply is ensured by the continuous action of cryo-clastism and rock falls, and is abundant in comparison to glacier transportation efficiency, due to the high ratio between the area of debris-providing rock walls and the glacier area $[15,75]$. Debris evacuation by glacier transport outside the LIA and 1920s moraines has become negligible since the first decades of the 20th Century, and at present these moraines have a damming effect on debris transported by glacifluvial processes. In the investigated time span, there were only low-magnitude debris flows, which locally redistributed small amounts of debris within the glacier area. High-magnitude events, comparable to those reported in 1993 and 1999 by Chiarle et al. (2007) [76], and responsible of large sediment erosion, where completely absent. The resulting increase in area and thickness of the debris mantle is an important negative feedback that is contributing to the preservation of the Montasio Glacier.

Even if a short reaction/response time is expected for this small and steep ice body, subject to high mass balance gradients [77], the phase with a positive cumulated mass balance between 2006 and 2014 was likely too short or discontinuous to lead sizeable variations in the front area. The variations in surface displacement rates described in Section 4.2, between 2010 and 2019, show that the lower half of the glacier tends towards stagnation and stationary thinning. This tendency is more evident in the central-western part of the glacier. The higher residual activity of the eastern portion is documented by its smaller deceleration, and by vertical displacement rates that became closer to zero, possibly related to the phase of temporary mass gain mentioned above. Nevertheless, the number of sinkholes has clearly increased also in this part of the front, suggesting low residual ice thickness beneath the debris layer.

Even if the measured surface displacement rates are typical of rock glaciers, the Montasio Glacier does not show the progressive transition from glacial to periglacial processes described for other small, avalanche-fed, and debris-covered glaciers in the Eastern Italian Alps [21,23,78,79]. These sites are originating rock glaciers or glacial-permafrost composite landforms, where the former accumulation area is downwasting, and the lower ablation area is evolving under permafrost conditions and generating active rock glaciers. We tend to exclude that such a transition is taking place on the Montasio Glacier, which completely lacks morphological features typical of active rock glaciers, such as transverse ridges and furrows, or a steep and advancing front. The limiting factors for a similar evolution of the Montasio Glacier are still poorly know, but are probably related to the lack of permafrost conditions (due to the low elevation, high snow accumulation, and absence of open-work deposits [80]), and to the residual activity of the glacier.

Outlining the possible future evolution of the Montasio Glacier, and of other ice bodies with similar characteristics, is not straightforward. Even if the presented observation series is rare for 
its length, further investigations are required to better understand how the climatic sensitivity of this glacier changes in the long term. As highlighted in this work, there is an important role played by the debris cover, which is a key negative feedback that acts to preserve the glacier remnants. Our results confirm a complex relationship between the glacier mass balance and the extent of the debris-covered area, which can change dramatically in the short term due to the wide fluctuations of the firn cover. However, additional investigations are required to highlight how the debris thickness and areal extent evolve in the long term, together with other important feedbacks associated with snow accumulation (e.g., the avalanche ratio), and ablation (e.g., the terrain shadowing). Effects from permafrost degradation in debris cover dynamics should be also taken into account in these studies, because the permafrost index map published by Boeckli et al. (2012) [80] indicates the possible presence of permafrost in the rock walls above the glacier.

\section{Concluding Remarks}

The results of our investigations on the Montasio Glacier, spanning the period from 2006 to 2019 , highlight how this glacier is currently subject to a low degree of imbalance, which is about one order of magnitude lower compared to the reference mass balance glaciers of the European Alps. The cumulative mass balance has been even positive until 2014, thanks to snow-rich accumulation seasons, which occurred in particular in 2009 and 2014.

This work provides statistically significant evidence of the dominant role played by solid precipitation in regulating the annual mass balance of this type of glacier, which benefits from thick and spatially concentrated snow accumulation by avalanches. These deposits are effectively shadowed by the same rock walls that contributes avalanches, and which also release debris (mainly cryo clasts) that accumulate over the glacier.

The progressive shrinking and thinning of the glacier, in association with the ongoing debris deposition and the low effectiveness of glacifluvial erosion, has led to the formation of a widespread and thick debris cover, in particular over the lower half of the glacier. This is the main negative feedback affecting the mass balance evolution of the Montasio Glacier, which is currently characterized by a low sensitivity to regional temperature fluctuations. Together with the thick avalanche deposits, the debris cover is also responsible for the very low balanced-budget AAR, around 0.30, which is among the lowest reported in the literature [18,20,81,82].

The progressive accumulation, thickening, and reworking of the debris cover, and the reduction in the climatic sensitivity of the glacier, are long-term processes that could not be fully investigated in the time span of our recent investigations. For this reason, a detailed reconstruction of the geometric variations and surface evolution of the Montasio Glacier before 2006 is in progress, and will be extended to the first direct observations at the beginning of the 20th Century. This additional study will enable an even better understanding of how the geometry and climatic sensitivity of this type of glaciers respond to sustained atmospheric changes, in order to outline their possible evolution in the next decades. Moreover, they will serve to clarify why some glacierized alpine environments shift towards periglacial/paraglacial conditioning, whereas others (such as the Montasio) preserve a dominant glacial conditioning.

Author Contributions: Conceptualization, L.C., F.C. and G.D.F.; Methodology, L.C., S.C., L.P. and J.D.M.; Validation, L.C., S.C., L.P. and J.D.M.; Formal analysis, L.P., S.C. and J.D.M.; Data curation, L.C., L.P., S.C., D.M. and J.D.M.; Writing-original draft preparation, J.D.M. and L.C.; Writing-review and editing, L.C., F.C., L.P., S.C., G.D.F., D.M. and J.D.M.; Visualization, J.D.M. and L.C.; Supervision, L.C. and F.C.; Funding acquisition, F.C., G.D.F. and L.C. All authors have read and agreed to the published version of the manuscript.

Funding: This study was carried out in the framework of two PhD studentships funded by the Universities of Udine and Trieste (Department of Agricultural, Food, Environmental and Animal Sciences-DI4A and Department of Life Sciences-DSV), and a PhD studentship funded by the University of Padova (Department of Land, Environment, Agriculture and Forestry-TeSAF). The study was also funded by (i) the Italian research program MIUR PRIN 2010-2011 “Response of Morphoclimatic System Dynamics to Global Changes and Related Geomorphological Hazards" (local and national coordinators G. Dalla Fontana and C. Baroni); (ii) the research program MIUR PRIN 2010-2011 20104ALME4-ITSE (local and national coordinators F. Cazorzi and M.A. Lenzi); (iii) the research 
program MIUR PRIN 2008 “La degradazione della criosfera nelle Alpi centro orientali. Analisi delle trasformazioni in atto attraverso lo studio di aree campione e di unità morfologiche chiave" (coordinator A. Carton); (iv) the University of Padova Junior Research Grant: "Sperimentazione di tecniche di rilievo LiDAR e TLS per lo studio della criosfera alpina".

Acknowledgments: The authors would like to thank the OSMER Office (Osservatorio Meteorologico Regionale) of the Autonomous Region of Friuli Venezia Giulia for providing access to regional meteorological datasets, and in particular Andrea Cicogna and Roberto Medeossi for their availability. A special thanks to the personnel of the "Direzione Centrale Risorse Agroalimentari, Forestali e Ittiche, Servizio Foreste e Corpo Forestale" office of the Autonomous Region of Friuli Venezia Giulia for their support during field activities. Thanks as well to Alberto Carton, Alberto Guarnieri, Simone Calligaro and Giovanni Andrea Baldassi, (University of Padova), Riccardo De Infanti and Giacomo Blasone (University of Udine) for their contribution during field activities and preliminary analyses. The authors would like to thank Bernhard Zagel for the updated data of Stubacher Sonnblickkees.

Conflicts of Interest: The authors declare no conflict of interest.

\section{References}

1. Pfeffer, W.T.; Arendt, A.A.; Bliss, A.; Bolch, T.; Cogley, J.G.; Gardner, A.S.; Hagen, J.O.; Hock, R.; Kaser, G.; Kienholz, C.; et al. The randolph glacier inventory: A globally complete inventory of glaciers. J. Glaciol. 2014, 60, 537-552. [CrossRef]

2. Paul, F.; Kääb, A.; Maisch, M.; Kellenberger, T.; Haeberli, W. Rapid disintegration of alpine glaciers observed with satellite data. Geophys. Res. Lett. 2004, 31. [CrossRef]

3. Huss, M.; Fischer, M. Sensitivity of very small glaciers in the swiss alps to future climate change. Front Earth Sci. 2016, 4, 1-17. [CrossRef]

4. Paul, F. Changes in glacier area in Tyrol, Austria, between 1969 and 1992 derived from landsat 5 thematic mapper and Austrian glacier inventory data. Int. J. Remote Sens. 2002, 23, 787-799. [CrossRef]

5. Lambrecht, A.; Kuhn, M. Glacier changes in the Austrian alps during the last three decades, derived from the new Austrian glacier inventory. Ann. Glaciol. 2007, 46, 177-184. [CrossRef]

6. Andreassen, L.M.; Paul, F.; Kääsignb, A.; Hausberg, J.E. Landsat-derived glacier inventory for Jotunheimen, Norway, and deduced glacier changes since the 1930s. Cryosphere 2008, 2, 131-145. [CrossRef]

7. Paul, F.; Haeberli, W. Spatial variability of glacier elevation changes in the Swiss Alps obtained from two digital elevation models. Geophys. Res. Lett. 2008, 35, 1-5. [CrossRef]

8. Carturan, L.; Filippi, R.; Seppi, R.; Gabrielli, P.; Notarnicola, C.; Bertoldi, L.; Paul, F.; Rastner, P.; Cazorzi, F.; Dinale, R.; et al. Area and volume loss of the glaciers in the ortles-cevedale group (Eastern Italian alps): Controls and imbalance of the remaining glaciers. Cryosphere 2013, 7, 1339-1359. [CrossRef]

9. Schmidt, S.; Nüsser, M. Changes of high altitude glaciers from 1969 to 2010 in the Trans-Himalayan Kang Yatze Massif, Ladakh, Northwest India. Arct. Antarct. Alp. Res. 2012, 44, 107-121. [CrossRef]

10. López-Moreno, J.I.; Nogués-Bravo, D.; Chueca-Cía, J.; Julían-Andrés, A. Change of topographic control on the extent of cirque glaciers since the little ice age. Geophys. Res. Lett. 2006, 33, 1-5. [CrossRef]

11. Chueca, J.; Julián, A.; López-Moreno, J.I. Recent evolution (1981-2005) of the Maladeta glaciers, pyrenees, Spain: Extent and volume losses and their relation with climatic and topographic factors. J. Glaciol. 2007, 53, 547-557. [CrossRef]

12. Kuhn, M. The mass balance of very small glaciers. Z. Für Gletsch. Und Glazialgeol. 1995, 31, 171-179.

13. DeBeer, C.M.; Sharp, M.J. Topographic influences on recent changes of very small glaciers in the Monashee Mountains, British Columbia, Canada. J. Glaciol. 2009, 55, 691-700. [CrossRef]

14. Grunewald, K.; Scheithauer, J. Europe's southernmost glaciers: Response and adaptation to climate change. J. Glaciol. 2010, 56, 129-142. [CrossRef]

15. Zemp, M.; Kääb, A.; Hoelzle, M.; Haeberli, W. GIS-based modelling of glacial sediment balance. Z. Fur Geomorphol. Suppl. 2005, 138, 113-129. [CrossRef]

16. Benn, D.; Evans, D.J.A. Glaciers E Glaciation, 2nd ed.; Hodder Education: London, UK, 2010; ISBN 9780340905791.

17. Carturan, L.; Baldassi, G.A.; Bondesan, A.; Calligaro, S.; Carton, A.; Cazorzi, F.; Dalla Fontana, G.; Francese, R.; Guarnieri, A.; Milan, N.; et al. Current behaviour and dynamics of the lowermost Italian Glacier (Montasio occidentale, Julian Alps). Geogr. Ann. Ser. A Phys. Geogr. 2013, 95, 79-96. [CrossRef]

18. Benn, D.I.; Lehmkuhl, F. Mass balance and equilibrium-line altitudes of glaciers in high-mountain environments. Quat. Int. 2000, 65-66, 15-29. [CrossRef] 
19. Cogley, J.G.; Hock, R.; Rasmussen, L.A.; Arendt, A.A.; Bauder, A.; Braithwaite, R.J.; Jansson, P.; Kaser, G.; Möller, M.; Nicholson, L.; et al. Glossary of Glacier Mass Balance and Related Terms, IHP-VII Technical Documents in Hydrology No.86, IACS Contribution No. 2; UNESCO-IHP: Paris, France, 2011.

20. Kern, Z.; László, P. Size specific steady-state accumulation-area ratio: An improvement for equilibrium-line estimation of small palaeoglaciers. Quat. Sci. Rev. 2010, 29, 2781-2787. [CrossRef]

21. Seppi, R.; Zanoner, T.; Carton, A.; Bondesan, A.; Francese, R.; Carturan, L.; Zumiani, M.; Giorgi, M.; Ninfo, A. Current transition from glacial to periglacial processes in the Dolomites (South-Eastern Alps). Geomorphology 2014, 228, 71-86. [CrossRef]

22. Bosson, J.B.; Lambiel, C. Internal structure and current evolution of very small debris-covered glacier systems located in alpine permafrost environments. Front. Earth Sci. 2016, 4. [CrossRef]

23. Seppi, R.; Carturan, L.; Carton, A.; Zanoner, T.; Zumiani, M.; Cazorzi, F.; Bertone, A.; Baroni, C.; Salvatore, M.C. Decoupled kinematics of two neighbouring permafrost creeping landforms in the Eastern Italian Alps. Earth Surf. Process. Landf. 2019, 44, 2703-2719. [CrossRef]

24. Serandrei Barbero, R.; Rabagliati, R.; Zecchetto, S. Analisi delle misure alle fronti dei ghiacciai delle Apli Giulie e correlazioni con i dati climatici. Geogr. Fis. Din. Quat. 1989, 12, 139-149.

25. Carturan, L.; Seppi, R. Comparison of current behavior of three glaciers in western Trentino (Italian Alps)-evoluzione recente di tre ghiacciai nel Trentino occidentale (Alpi Italiane). In Proceedings of the Geoitalia 2009 Congress, EPITOME, Rimini, Italy, 9-11 September 2009; Volume 3, p. 298.

26. Colucci, R.R.; Guglielmin, M. Precipitation-temperature changes and evolution of a small glacier in the southeastern European Alps during the last 90 years. Int. J. Climatol. 2015, 35, 2783-2797. [CrossRef]

27. Passalacqua, P.; Belmont, P.; Staley, D.M.; Simley, J.D.; Arrowsmith, J.R.; Bode, C.A.; Crosby, C.; DeLong, S.B.; Glenn, N.F.; Kelly, S.A.; et al. Analyzing high resolution topography for advancing the understanding of mass and energy transfer through landscapes: A review. Earth-Sci. Rev. 2015, 148, 174-193. [CrossRef]

28. Lague, D. Terrestrial Laser Scanner Applied to Fluvial Geomorphology. In Developments in Earth Surface Processes, 1st ed.; Elsevier B.V.: Amsterdam, The Netherlands, 2020; Volume 23, pp. 231-254. ISBN 9780444641779.

29. Eltner, A.; Sofia, G. Structure from Motion Photogrammetric Technique. In Developments in Earth Surface Processes, 1st ed.; Elsevier B.V.: Amsterdam, The Netherlands, 2020; Volume 23, pp. 1-24. ISBN 9780444641779.

30. Tarolli, P.; Arrowsmith, J.R.; Vivoni, E.R. Understanding earth surface processes from remotely sensed digital terrain models. Geomorphology 2009, 113, 1-3. [CrossRef]

31. Fischer, M.; Huss, M.; Kummert, M.; Hoelzle, M. Application and validation of long-range terrestrial laser scanning to monitor the mass balance of very small glaciers in the Swiss alps. Cryosphere 2016, 10, 1279-1295. [CrossRef]

32. Piermattei, L.; Carturan, L.; Guarnieri, A. Use of terrestrial photogrammetry based on structure-from-motion for mass balance estimation of a small glacier in the Italian alps. Earth Surf. Process. Landf. 2015, 40, 1791-1802. [CrossRef]

33. Piermattei, L.; Carturan, L.; De Blasi, F.; Tarolli, P.; Dalla Fontana, G.; Vettore, A.; Pfeifer, N. Suitability of ground-based SfM-MVS for monitoring glacial and periglacial processes. Earth Surf. Dyn. 2016, 4, 425-443. [CrossRef]

34. Cucchiaro, S.; Cavalli, M.; Vericat, D.; Crema, S.; Llena, M.; Beinat, A.; Marchi, L.; Cazorzi, F. Monitoring topographic changes through $4 \mathrm{D}$-structure-from-motion photogrammetry: Application to a debris-flow channel. Environ. Earth Sci. 2018, 77, 632. [CrossRef]

35. Piermattei, L.; Karel, W.; Vettore, A.; Pfeifer, N. Panorama image sets for terrestrial photogrammetric surveys. ISPRS Ann. Photogramm. Remote Sens. Spat. Inf. Sci. 2016, 3, 159-166. [CrossRef]

36. Cucchiaro, S.; Maset, E.; Fusiello, A.; Cazorzi, F.; Weiss, V.E. 4D-Sfm photogrammetry for monitoring sediment dynamics in a debris-flow catchment: Software testing and results comparison. Int. Arch. Photogramm. Remote. Sens. Spat. Inf. Sci. 2018, 42, 4-7. [CrossRef]

37. Loye, A.; Jaboyedoff, M.; Isaac Theule, J.; Liébault, F. Headwater sediment dynamics in a debris flow catchment constrained by high-resolution topographic surveys. Earth Surf. Dyn. 2016, 4, 489-513. [CrossRef]

38. World Glacier Inventory (WGI). Available online: https://nsidc.org/ (accessed on 26 March 2020). 
39. Haeberli, W.; Bösch, H.; Scherler, K.; Østrem, G.; Wallén, C.C. World Glacier Inventory; Status 1988. A Contribution to the Global Environ-Ment Monitoring System (GEMS) and the International Hydrological Programme; International Association of Hydrological Sciences; 1ARS Press: Nairobi, Kenya-United Nation, 1989; ISBN 92-807-1217-9.

40. Cucchiaro, S.; Maset, E.; Cavalli, M.; Crema, S.; Marchi, L.; Beinat, A.; Cazorzi, F. How does co-registration affect geomorphic change estimates in multi-temporal surveys? GISci. Remote Sens. 2020, 57, 611-632. [CrossRef]

41. Agisoft PhotoScan.

42. Pfeifer, N.; Mandlburger, G.; Otepka, J.; Karel, W. OPALS-A framework for airborne laser scanning data analysis. Comput. Environ. Urban Syst. 2014, 45, 125-136. [CrossRef]

43. Sorge, E. Glaziologische untersuchungen in eismitte-glaciological research at eismitte. Wiss.-Ergeb. Dtsch. Groenl. Exped. Alfred Wegener. 1935, 3, 270.

44. Ai, S.; Yan, B.; Wang, Z.; Yan, M. A decadal record of inter-annual surface ice flow from pedersenbreen, svalbard (2005-15). Polar Sci. 2019, 22. [CrossRef]

45. World Meteorological Organization. Climate Observations and Climate Data Management Guidelines; WMO: Geneva, Switzerland, 2009.

46. Baldassi, G.A. Analisi su Base Climatologica Delle Variazioni Storiche Del Ghiacciaio Del Montasio (FVG). Master's Thesis, University degli Stud di Padova, Padova, Italy, 2010.

47. Schwarb, M. The Alpine Precipitation Climate: Evaluation of a High-Resolution Analysis Scheme Using Comprehensive Rain-Gauge Data. Ph.D. Thesis, ETH Zurich, Zurich, Switzerland, 2000.

48. Klein Tank, A.M.G.; Wijngaard, J.B.; Können, G.P.; Böhm, R.; Demarée, G.; Gocheva, A.; Mileta, M.; Pashiardis, S.; Hejkrlik, L.; Kern-Hansen, C.; et al. Daily dataset of 20th-century surface air temperature and precipitation series for the European climate assessment. Int. J. Climatol. 2002, 22, 1441-1453. [CrossRef]

49. European Climate Assessment \& Dataset. Available online: https://www.ecad.eu/ (accessed on 20 March 2020).

50. Zemp, M.; Gärtner-Roer, I.; Nussbaumer, S.U.; Bannwart, J.; Rastner, P.; Paul, F.; Hoelzle, M. WGMS 2020. Global Glacier Change Bulletin No. 3 (2016-2017); WGMS: Zurich, Switzerland, 2020.

51. World Glacier Monitoring Service. WGMS online dataset. Available online: https://wgms.ch/latest-glaciermass-balance-data/ (accessed on 5 June 2020).

52. Zagel, B.; Slupetzky, H. LTER Site Stubacher Sonnblickkees, Mass Balance. Available online: https: //deims.org/f904bf5e-60a5-4d0d-b8b9-6ca009fbcb9f (accessed on 22 June 2019).

53. Observatoire des Sciences de l'Univers de Grenoble. Service d'Observation GLACIOCLIM. Available online: https://glacioclim.osug.fr/Donnees-des-Alpes (accessed on 6 July 2020).

54. Bavarian Academy of Sciences and Humanities Website. Available online: https://geo.badw.de/vernagtfernerdigital/massenbilanz.html (accessed on 27 July 2020).

55. Rotach, M.; Prinz, R. Hintereis-und Kesselwandferner Massenhaushaltsstudien, Abschlussbericht über das Haushaltsjahr 2018/19; Univesität Innsbruck: Innsbruck, Austria, 2019.

56. Baroni, C.; Bondesan, A.; Luca, C.; Chiarle, M. (Eds.) Preliminary Results on Antarctic Albedo from Remote Sensing Observations. Geogr. Fis. Dinam. Quat. 2019, 42. [CrossRef]

57. Serrano, E.; González-trueba, J.J.; Sanjosé, J.J.; Del río, L.M. Ice patch origin, evolution and dynamics in a temperate high mountain environment: The jou negro, picos de europa (nw spain). Geogr. Ann. Ser. A Phys. Geogr. 2011, 93, 57-70. [CrossRef]

58. Zemp, M.; Paul, F.; Hoelzle, M.; Haeberli, W. Glacier fluctuations in the European Alps 1850-2000: An overview and spatio-temporal analysis of available data. Darkening Peaks Glacial Retreat Sci. Soc. Context 2008, 152-167. [CrossRef]

59. Fischer, A. Comparison of direct and geodetic mass balances on a multi-annual time scale. Cryosphere 2011, 5, 107-124. [CrossRef]

60. Zemp, M.; Thibert, E.; Huss, M.; Stumm, D.; Rolstad Denby, C.; Nuth, C.; Nussbaumer, S.U.; Moholdt, G.; Mercer, A.; Mayer, C.; et al. Reanalysing glacier mass balance measurement series. Cryosphere 2013, 7, 1227-1245. [CrossRef]

61. Abermann, J.; Lambrecht, A.; Fischer, A.; Kuhn, M. Quantifying changes and trends in glacier area and volume in the Austrian Ötztal Alps (1969-1997-2006). Cryosphere 2009, 3, 205-215. [CrossRef] 
62. Fischer, M.; Huss, M.; Hoelzle, M. Surface elevation and mass changes of all swiss glaciers 1980-2010. Cryosphere 2015, 9, 525-540. [CrossRef]

63. Sommer, C.; Malz, P.; Seehaus, T.C.; Lippl, S.; Zemp, M.; Braun, M.H. Rapid glacier retreat and downwasting throughout the European Alps in the early 21st century. Nat. Commun. 2020, 11, 3209. [CrossRef] [PubMed]

64. Zemp, M.; Huss, M.; Thibert, E.; Eckert, N.; McNabb, R.; Huber, J.; Barandun, M.; Machguth, H.; Nussbaumer, S.U.; Gärtner-Roer, I.; et al. Global glacier mass changes and their contributions to sea-level rise from 1961 to 2016. Nature 2019, 568, 382-386. [CrossRef] [PubMed]

65. Carrivick, J.L.; Berry, K.; Geilhausen, M.; James, W.H.M.; Williams, C.; Brown, L.E.; Rippin, D.M.; Carver, S.J. Decadal-scale changes of the ödenwinkelkees, central austria, suggest increasing control of topography and evolution towards steady state. Geogr. Ann. Ser. A Phys. Geogr. 2015, 97, 543-562. [CrossRef]

66. Colucci, R.R. Geomorphic influence on small glacier response to post-little ice age climate warming: Julian Alps, Europe. Earth Surf. Process. Landf. 2016, 41, 1227-1240. [CrossRef]

67. Scotti, R.; Brardinoni, F. Evaluating millennial to contemporary time scales of glacier change in Val Viola, central Italian Alps. Geogr. Ann. Ser. A Phys. Geogr. 2018, 100, 319-339. [CrossRef]

68. Dahl, S.O.; Nesje, A. Paleoclimatic implications based on equilibrium-line altitude depressions of reconstructed Younger dryas and holocene cirque glaciers in inner Nordfjord, western Norway. Palaeogeogr. Palaeoclim. Palaeoecol. 1992, 94, 87-97. [CrossRef]

69. Kulkarni, A.V.; Bahuguna, I.M.; Rathore, B.P.; Singh, S.K.; Randhawa, S.S.; Sood, R.K.; Dhar, S. Glacial retreat in Himalaya using Indian remote sensing satellite data. Curr. Sci. 2007, 92. [CrossRef]

70. Winsvold, S.H.; Andreassen, L.M.; Kienholz, C. Glacier area and length changes in Norway from repeat inventories. Cryosphere 2014, 8, 1885-1903. [CrossRef]

71. Schmidt, S.; Nüsser, M. Changes of high altitude glaciers in the trans-himalaya of ladakh over the past five decades (1969-2016). Geosciences 2017, 7, 27. [CrossRef]

72. Bhambri, R.; Bolch, T.; Chaujar, R.K.; Kulshreshtha, S.C. Glacier changes in the garhwal himalaya, India, from 1968 to 2006 based on remote sensing. J. Glaciol. 2011, 57, 543-556. [CrossRef]

73. Schöner, W.; Auer, I.; Böhm, R. Climate variability and glacier reaction in the Austrian eastern Alps. Ann. Glaciol. 2000, 31, 31-38. [CrossRef]

74. Hughes, P.D. Response of a montenegro glacier to extreme summer heatwaves in 2003 and 2007. Geogr. Ann. Ser. A Phys. Geogr. 2008, 90, 259-267. [CrossRef]

75. Haeberli, W. Factors influencing the distribution of rocky and sedimentary glacier beds-hydraulic effects at the glacier bed and related phenomena. Mitt. Vers. Für Wasserbau Hydrol. Und Glaziologie 1986, 90, 48-49.

76. Chiarle, M.; Iannotti, S.; Mortara, G.; Deline, P. Recent debris flow occurrences associated with glaciers in the Alps. Glob. Planet. Chang. 2007, 56, 123-136. [CrossRef]

77. Bahr, D.B.; Pfeffer, W.T.; Sassolas, C.; Meier, M.F. Response time of glaciers as a function of size and mass balance: 1. theory. J. Geophys. Res. Solid Earth 1998, 103, 9777-9782. [CrossRef]

78. Krainer, K.; Lang, K.; Hausmann, H. Active rock glaciers at croda Rossa/Hohe gaisl, eastern Dolomites (Alto Adige/South Tyrol, Northern Italy). Geogr. Fis. E Din. Quat. 2010, 33, 25-36.

79. Krainer, K.; Mussner, L.; Behm, M.; Hausmann, H. Multi-disciplinary investigation of an active rock glacier in the sella group (Dolomites; Northern Italy). Austrian J. Earth Sci. 2012, 105, 48-62.

80. Boeckli, L.; Brenning, A.; Gruber, S.; Noetzli, J. Permafrost distribution in the European Alps: Calculation and evaluation of an index map and summary statistics. Cryosph 2012, 6, 807-820. [CrossRef]

81. Clark, D.H.; Clark, M.M.; Gillespie, A.R. Debris-Covered Glaciers in the Sierra Nevada, California, and their implications for snowline reconstructions. Quat. Res. 1994, 41, 139-153. [CrossRef]

82. Kulkarni, A.V. Mass balance of himalayan glaciers using AAR and ELA methods. J. Glaciol. 1992, 38, 101-104. [CrossRef]

(C) 2020 by the authors. Licensee MDPI, Basel, Switzerland. This article is an open access article distributed under the terms and conditions of the Creative Commons Attribution (CC BY) license (http://creativecommons.org/licenses/by/4.0/). 